\title{
The Political Lives and Times of Enrique P. Osés (1928-1944)
}

\author{
MARCUS KLEIN* \\ Independent Research
}

\section{Introduction}

In late 1944, Enrique P. Osés, his aim in life of a fascist Argentina irretrievably wrecked, disappeared from the public scene. With the retreat "into complete obscurity" (Rock 1995: 277, n. 44) ${ }^{1}$ the nacionalista movement lost one of its most radical, outspoken, intransigent, and controversial representatives. It also lost one of its most important and influential figures, notwithstanding the fact that Osés soon fell into oblivion. Since the early 1930s he had, as editor of the nacionalista dailies Crisol (1932-1939), El Pampero (1939-1944), and El Federal (1944) (the successor paper of El Pampero), influenced the orientation of significant sectors of the more extreme sectors of Nacionalismo, as well as the movement's perception by the Argentine public in general. Moreover, by the end of the decennium Osés, a "talented agitator and orator" who tirelessly preached his convictions (Buchrucker 1982: 191), had even partly pushed through his claims to leadership within the nacionalista movement; in Santa $\mathrm{Fe}$ and Mendoza the Unión Nacionalista, the dominant organisation in these two provinces, accepted him as its leader.

One reason for the rapid fall into obscurity was that Osés, unlike other prominent nacionalista militants, never published a book, or memoirs after his retirement. He never laid down his convictions in a (more or less) coherent way. ${ }^{2}$ Another important factor, and arguably the more decisive one, was his

* I would like to thank Flavia Fiorucci and Federico Finchelstein for their thoughtful and stimulating comments on earlier drafts of the paper as well as Martín Recchia and especially Marsha Schlesinger for undertaking invaluable additional research in Buenos Aires.

1 According to Rock, he died in late 1954. Santillán (1960: 96) states on the other hand that Osés left journalism in 1945 and subsequently dedicated himself to commerce and industry, dying in December 1956.

2 This also means that, in order to comprehend and analyse his ideas, one has to rely on his countless editorials and numerous speeches, published in Criterio, Crisol and El 
well-known collaboration with the Third Reich. Immediately after the outbreak of the Second World War Nazi Germany had won the virulent anti-Semite and ardent devotee of the Fuhrer over to the publication of El Pampero, which was, until 1942, when Manuel Fresco, the former Conservative governor of the province of Buenos Aires, began to publish Cabildo, "the only nationalist newspaper in Buenos Aires that pretended to compete with the popular dailies" (Rennie 1945: 273). In view of the Third Reich's defeat, and the detailed revelation of the enormous atrocities it had been responsible for, the next generation of Nacionalistas was not interested in cultivating the image of a man who had maintained close relations with Nazism. After 1945 a known collaborator could not serve as a role model.

Osés was a rather unpleasant person, never missing a chance to show his hatred for his opponents, ${ }^{3}$ even fellow Nacionalistas. And he was "of very limited intellectual relevance" (Nascimbene / Neuman 1993: 140, n. 43). ${ }^{4}$ Yet, whatever justified reservations one might have, his influence within the nacionalista movement should not be underestimated. ${ }^{5}$ This chapter will reconstruct Osés relatively short public career. It will discuss his activities between the late 1920s and the mid-1940s and provide an assessment of his programmatic positions, showing its continuities as well discontinuities over time. In more general terms, Osés will serve as a (radical) example of the developments and changes the nacionalista movement experienced during the period under consideration. I will argue that Osés, as the 1930s progressed, became more extreme. At the end of the decennium he can be characterised as a fascist. ${ }^{6}$

Pampero over the years. They were "sloganeering" and "frequently incoherent" (Rock 1995: 107), as even some supporters occasionally noted. For the reaction of a follower, cf. Osés (1941b: 80). Published in November 1941, the booklet reproduced a series of articles Osés had written during his detention in Villa Devoto in May of the same year.

3 El Pampero described, for example, the US-American author and journalist Waldo David Frank as "the Yankee-Jew Frank". Frank, in turn, showed little restraint either, referring to Osés as "the rat who directs the nazi sheet" (Frank 1944: 57 and 128).

4 Spektorowski (2003: 174) on the other hand describes Osés as one of the "major...nationalist intellectuals". I agree with Nascimbene and Neuman on this point. Osés's thinking does not merit the characterisation "intellectual".

5 As far as I am aware, no single article or book chapter has been published about Osés.

6 This point is related to the ongoing debate about the nature of the Nacionalistas. For an insightful summary of the existing secondary literature, see Finchelstein (2002: 10-27). The nacionalista movement underwent a process of radicalisation during the Infamous Decade, undoubtedly the period when it was at its strongest. This process was neither linear nor did it effect all Nacionalistas to the same extent. But whereas in the early 1930s no single nacionalista group (or militant) can be described as fascist, the situation later in the decade was very different. And Osés's development is illustrative of this process. 


\section{The "Divine Truths" of the Catholic Church}

In the late 1920s, the future intellectual and political development of Osés, in his early thirties at the time, ${ }^{7}$ was by no means foreseeable. Osés started his career in Convivio, a group dedicated to the promotion of young writers and artists that had emerged from the Comisión de Artes y Letras de los Cursos de Cultura Católica. ${ }^{8}$ In March 1928 he joined Criterio, a new magazine directed by Atilio Dell'Oro Maini (a leading figure of Convivio) and launched to ensure the wider dissemination of the Catholic Church's ideas. As Criterio's "theatre critic", Osés was one of its sixty permanent national collaborators. Reflecting his subordinate position within the group of "respectable Catholics" and "good believers" (Ruschi Crespo 1998: 92 and 148) editing the publication, which primarily aimed its authoritarian message at the "traditional proprietary sectors" of Argentine society (Rapalo 1990: 53), during the first two years of its existence Osés kept to the sidelines. In his articles he focused on dramatic criticism, and in his lectures he talked about the situation of the Argentine theatre.

Behind the scenes Osés must have been very active, however, scheming for his rise through the ranks of Criterio. In early 1930 his machinations finally bore fruit. Following a dispute between Dell'Oro Maini and the Argentine hierarchy about the programmatic orientation of the magazine -a dispute that had its origins in Pope Pius XI's efforts to unite "the faithful under the inspiration of the Catholic Action"- the young theatre critic assumed its provisional editorship (Lafleur / Provenzano / Alonso 1968: 127). This change of personnel signalled a programmatic reorientation of the publication. While retaining its anti-democratic discourse and attacks on the administration of President Hipólito Yrigoyen (1928-1930), under the direction of Osés, who represented a group of militant Catholics identifying with the interests of the Acción Católica Argentina, Criterio's tone became "more confessional". In accordance with the Church's explicit wishes, it devoted less space to political problems and paid more attention to Catholic doctrine (Zanatta 1996: 48-49; Rapalo 1990: 55); it turned into an outspoken advocate of the Church's interests and standpoints. Moreover, literary contributions disappeared slowly but surely from the publication that had originally functioned as a "magazine for young, avant-garde authors, such as Eduardo Mallea and Jorge Luis Borges" (Dolkart 1993: 80-81).

7 According to Santillán (1960: 95), Osés was born in 1897. He does not provide any information about his precise birthday or place of birth.

8 The Comisión was an institution sponsored by the Catholic Church to disseminate its authoritarian concepts and to "create the elite that in its judgement the country needed" (Rapalo 1990: 53). 
With Osés as its editor Criterio defended the sphere of influence of the Church vis-à-vis other political and social protagonists and its claim to an autonomous role in Argentine society. The rise of "Nacionalismo", the term Osés initially preferred when referring to European fascism, served as the point of reference for expressing its matters of concern. For the editor of the Catholic magazine, fascism's emphasis on the state was "a false conception of the life of people" that amounted to "heresy". It was an ideology completely unacceptable for the Church, since it was "pagan, limited, earthly", and "materialised man". By condemning "the nationalist error", Osés argued moreover, the Church "not only defended the truth but also freedom. Nobody has the right to teach that the last word in life is the greatness of the country, the strength of the nation. These are not supreme concepts."

In the same vein, the conflict between the Fascist regime and the Vatican about the Italian branch of the Acción Católica in general and its role in educating youth in particular, addressed by the papal encyclical Non abbiamo bisogno in late June 1931, underlined the ideological abyss that separated fascism and Catholicism. It clearly revealed, an editorial in Criterio stated, the fundamental differences between the two opponents:

Los filósofos del fascismo, tipo [Giovanni] Gentile, han procurado darle contenido ideológico a esa fuerza política, que en principio fue tan sólo un movimiento de reacción contra el liberalismo y el comunismo. Y sólo han logrado quintaesenciar un concepto: el nacionalismo que, llevado a sus extremas consecuencias cae en la condenación del Syllabus.... Sostener esa posición, como lo hace el Duce, implica una tiranía sin límites, que se iguala a la bolchevique. ${ }^{10}$

The only "divine truths", the editor of the Catholic magazine affirmed, could be found in the teachings of the Church, which had "to be accepted formally and unreservedly." 11

During his editorship, Criterio also voiced its low opinion of Adolf Hitler, notwithstanding Osés's beginning anti-Semitism (Rapalo 1990: 66, n. 66). In 1931 it described the leader of the German National Socialists as "a professional agitator" whose "talents as ruler have to remain, luckily for Europe, unused (inéditos)" (as quoted in Montserrat 1998: 18). At the time, Osés still searched for his heroes in the Argentine. Like the small group of militant Nacionalistas organised in the Liga Republicana (an offspring of the journal La Nueva República) (Buchrucker 1982: 89-91; Barbero / Devoto 1983: 149-

\footnotetext{
$9 \quad$ Criterio 20 March 1930: 371.

10 Criterio 16 July 1931: 73-74, italics in the original.

11 Criterio 24 March 1932: 373.
} 
153; Devoto 2002: 159-205), he found his idol in José F. Uriburu, the retired army general and member of the traditional oligarchy who led the "Revolution of 1930", as its apologists called the military coup against the democratically elected government of Yrigoyen. The Catholic magazine "emphatically celebrated the triumph" over the historical leader of the Unión Cívica Radical (Zanatta 1996: 51-52). In accordance with its marked anti-democratic attitude, it subsequently endorsed the tentative proposals of the provisional government that aimed at the restriction of the franchise as well as the abolition of parliamentary democracy, which should be replaced by a corporatist order. Some of Criterio's backers, namely Joaquín de Anchorena, Ernesto Bosch, and Enrique Santamarina, even assumed important roles in the revolutionary regime (Rapalo 1990: 53).

Given its anti-democratic basic convictions, its institutional links with the Church, as well as its close relations with the traditional oligarchy, which again had assumed power after September 1930, it came as no surprise that Criterio was not happy about the relatively quick end of the Uriburu regime. From its point of view this development was particularly troubling because it had brought about an "enhanced role for the church in Argentine institutions" (Dolkart 1993: 81). Since the return of democratic rule, albeit one controlled by the oligarchy, was unavoidable -the putative revolutionary leader failed to ensure enough support for his corporatist proposal (Klein 2002: 12-13)-, Criterio endorsed General Agustín P. Justo (1932-1938). Uriburu's co-conspirator and successor in the Casa Rosada, who was elected in a contest marred by electoral fraud and voter intimidation, was seen as the best option to defend the Church's regained strength. Justo was the person, Osés pointed out after his inauguration in mid-February 1932, on whom hopes were pinned: "The people do not expect anything from parliament and everything from the new president." 12

With this positive attitude the editor of the Catholic magazine expressed a position that was at variance with the militant nacionalista camp. Seeing Justo "as an agent of the oligarchy and enemy of Uriburu" who had deceived his comrade-in-arms, it only "unhappily acquiesced in his victory" (Mc Gee Deutsch 1999: 204). Osés needed more time to realise that Justo did not intend to carry out Uriburu's (dubious) revolutionary objectives. Yet once he had reached this point Osés emerged as one of the most outspoken critics of the president and the conservative sectors backing him. And he also left behind his earlier life as a "devout representative of a social reformism" that was based on the papal social encyclicals Rerum Novarum and Quadragessimo

12 Criterio 18 Feb. 1932: 202. 
Anno. ${ }^{13} \mathrm{He}$ became an ardent admirer of European fascism in general and Hitler in particular, a man Criterio had criticised so strongly under his editorship. With the move to Crisol, the nacionalista daily he took over in June 1932, he began a new phase in his intellectual and political career.

\section{¡Heil Hitler!}

During the first four months of its existence Crisol, founded in February 1932, had focused on the activities of the Acción Católica Argentina, announcing its meetings and public manifestations and reproducing its statements and declarations. The various nacionalista groups, most notably the Legión Cívica Argentina, the strongest and most significant organisation of the early 1930s (Cerdeira et al. 1989; Klein 2002), were hardly mentioned in the daily, on the other hand. After Osés assumed sole responsibility for the programmatic orientation of the newspaper, ${ }^{14}$ the situation changed dramatically, suggesting that a rift, which also had probably led to his replacement at Criterio, had opened between the former editor of the Catholic journal and the Catholic layorganisation controlling it. Crisol became the mouthpiece of the "more strident voices" within the nacionalista camp (Dolkart 1993: 72). Reports about their meetings prominently featured in its pages, and leading Nacionalistas wrote "with a certain regularity" in it (Zuleta Alvarez 1975: 285).

At the same time Osés, a gifted journalist who "distinguished himself by the mordant violence of his sarcasm" (Zuleta Alvarez 1975: 285), emerged as a representative of the more radical currents of the movement; he became "a virulent opponent of the oligarchy and therefore of the Justo government" (Dolkart 1993: 72). He particularly criticized that Justo and the traditional elite, after having "fiddled with (falsificó) the revolution of September", defended "the institutional normality" with all possible "transgressions" (Osés 1937: 18). ${ }^{15}$ For Osés, who held the opinion that liberal democracy had been responsible for the destruction of the basic values and pillars of the Argentine nation -the family, corporations, and the $\mathrm{Church}^{16}$-, the defence of a parliamentary regime based on political parties and the Sáenz Peña Law was unacceptable and only furthered the decline of "a virile people." ${ }^{17}$ It was, he argued in 1936,

\footnotetext{
13 Buchrucker (1982: 191); for encyclicals, see Criterio 5 May 1932: 127.

14 Crisol 10 June 1932: 1.

15 The booklet reproduced a series of editorials Osés had published in Crisol in August 1937.

16 Crisol 15 April 1936: 1.

17 Osés (1937: 24).
} 
un régimen falso, de espaldas al bienestar verdadero de la República, y mediante el cual, todos los desbordes políticos -fraudes, violencias, coacciones, chanchullos electorales, avasallamiento de autonomías provinciales, sometimiento claudicante del P[oder] E[jecutivo] a un Congreso que no representa sino intereses partidariosson posibles y, además, inevitables. ${ }^{18}$

By adhering to it, the conservative sectors and the president betrayed "the moral and material interests of the fatherland."19

From the point of view of the editor of Crisol a direct and palpable result of this unwillingness to change course and completely break with the liberal traditions was the rise of "the red social subversion", ${ }^{20}$ a term invariably covering all manifestations of leftist and progressive politics in Osés's, and other Nacionalista's, universe. The Justo administration was the main culprit, notwithstanding the fact that it "never flinched from using repression against the [trade] unions" (Rock 1993: 183). Osés tirelessly asserted that the conservative government, although it "perfectly" knew that "social discipline" had to come from above, had not taken "any single decisive measure" to "contain the reds". Because of this "complicity" communist agitators had infiltrated schools, the universities, trade unions, and the agricultural sector. ${ }^{21}$ Crucially, this "work of Soviet penetration" further undermined "the spirit" of the Argentine nation, already weakened by liberalism. ${ }^{22}$

Like other leading Nacionalistas, for instance the virulently anti-Semitic Carlos Silveyra, on more than one occasion Osés maintained that the leaders of trade unions, which he denounced as "costly, bureaucratic organisations or dangerous bunches of murderers", were directly paid by Moscow. ${ }^{23}$ Such statements did not only underline his obsession with leftist subversion; they also revealed his general distrust of the (organised) working class, sporadic statements to the contrary notwithstanding. ${ }^{24}$ At the same time, they betrayed his initial lack of concern (and interest in) social problems. Only during the late 1930s the demands for social justice, which went hand in hand with the toning down of his elitist discourse, became an integral part of his worldview. In this respect Osés underwent a development similar to that of the Civic

18 Osés (1936: 19). The booklet reproduced a series of editorials Osés had published in Crisol in March and April 1936.

19 Osés (1937: 28).

20 Osés (1936: 27).

21 Osés (1936: 27 and 18).

22 Osés (1936: 17).

23 Crisol 28 June 1934, as quoted in Buchrucker (1982: 225-226); for Silveyra, see Silveyra (1933); (1936).

24 See Buchrucker 1982: 226. 
Legion, which also assumed more radical and populist positions as the decade progressed (Klein 2002: 20-23). ${ }^{25}$

By the mid-1930s, after having remained conspicuously silent about the signing of the Roca-Runciman treaty between Great Britain and Argentina in 1933 (Zuleta Alvarez 1975: 285), which "[m]any Argentines perceived....as a humiliating display of national subservience" and as an move that "protected the core of the elite, the cattle fatteners, at a high cost to the rest of society" (Mc Gee Deutsch 1999: 205), Osés took up the idea of economic dependency. Like the overwhelming majority of Nacionalistas he belatedly followed the argumentation developed by Rodolfo and Julio Irazusta in their landmark book about the relationship between Argentina and Britain, written in 1934 in response to the pact. ${ }^{26}$ Once he had appropriated their accusations, he again displayed his typical verbal aggressiveness. He attacked "the great extranational forces of monopolistic (trustificada) capital" that, with the support of its Argentine allies, the traditional oligarchy, had been organised "for the absorption of our material wealth". ${ }^{27}$ Through Crisol he also proposed to nationalise "all 'trusts' and public utility companies", which were, to a large extent, British-owned. ${ }^{28}$

The criticism of foreign-owned companies and the idea that "the dependent nations of Latin America", not least the Argentine, "should be part of the fascist revolutionary international" "against the Western democratic powers" that only exploited them (Spektorowski 2003: 126), went hand in hand with demands for greater economic self-sufficiency. ${ }^{29}$ Despite these proposals, the break with Argentina's economic liberal tradition was not complete, though. Osés's (rare) statements on economic issues still betrayed the strength and lasting influence of the traditions he criticised so vehemently. For one, he never questioned the capitalist organisation of the country's economy as such. Crisol "continued to oppose economic planning for being too close to "state socialism"” (Rock 1995: 121). Nor did he propose a policy of industrialisation, which could have reduced the country's dependency on the agricultural sector.

25 At the same time, he never changed his traditionalist position concerning women. His paper strongly opposed female suffrage (Buchrucker 1982: 215), and "described the growing numbers of women entering the labor force as an 'invasion' and 'an inversion of Christian society'" (Crisol 12 June 1936, as quoted in Rock 1995: 110). Juan E. Carulla, the editor of Bandera Argentina, wholeheartedly shared Osés's reservations as regards women (Rock 1995: 80). Irazusta (1934). For assessment of the book and contemporary reactions to it, see Quattrocchi-Woisson (1995: 106-125). 
Indeed, Osés praised "the man of the country" as the "producer" of the nation's wealth. ${ }^{30}$

His thoughts on the economic crisis that the country experienced in the early 1930s as a result of the Great Depression did not betray any attempt of analysis. He simply put the blame squarely on the shoulders of the Jews. Wasn't "the entire modern, barbarous and suicidal capitalist system", he asked in late 1932, "the most monstrous conjunction of interests of the immense Jewish autocracy, which can only live on the misery of the majority"? ${ }^{31}$ For Osés, the answer to this rhetorical question was obvious. Adopting a position commonly shared by other radical Argentine anti-Semites of the 1930s, for instance the former socialist Ramón Doll (Spektorowski 1993: 105-108), he asserted that capitalism was in fact only one instrument in a vast Jewish conspiracy that ultimately strove for the "domination of the world". Everything was geared to "the advent of the Soviet regime", "the pinnacle of Jewish imperialism". The plan, which had been laid down in The Protocols of the Elders of Zion, would "be fulfilled inexorably". 32

Through Crisol, the self-styled "anti-Jewish newspaper" that "published scurrilous lies in its 'Jewish news column"” (Mc Gee Deutsch 1986: 115), Osés wanted to draw attention to what he saw as a mortal danger for the country. Accordingly, he did not shy away from disseminating venomous falsehoods about the Jewish community. Osés consistently exaggerated the number of Jews living in the country, ${ }^{33}$ and tirelessly warned of the "Jewish invasion of our fatherland", especially by refugees coming from Central and Eastern Europe, and the infiltration of the armed forces. ${ }^{34}$ Moreover Osés, who as early as October 1932 defended the "bloody persecution" of Jews as a legitimate means in the struggle against an "overbearing invader", ${ }^{35}$ did not show any restraint in his proposals regarding the treatment of Argentina's Jews. In October 1936 he proposed, for example, to deprive them of fundamental civil rights, including citizenship, and asked for the establishment of ghettos and the introduction of identification signs. Ultimately, he wanted their expulsion from the country. ${ }^{36}$

30 Crisol 19 Aug. 1934, as quoted in Rock 1995: 102.

31 Crisol 2 Oct. 1932: 1.

32 Crisol 2 Oct. 1932: 1.

33 Crisol 6 May 1936: 1. He asserted that up to 1.5 million Jews lived in the Argentine (around ten per cent of the population) while in reality there were only 250,000 (or less than two per cent).

36 Crisol 18 Oct. 1936: 3; (Buchrucker 1982: 243). Even some leading Catholic Nacionalistas, most notably the priest Gustavo Franceschi, Osés's successor as editor of Criterio 
It should come as no surprise that Osés justified every single anti-Semitic measure of the Third Reich against the "wicked race." ${ }^{37}$ Indeed, while most Nacionalistas and "essentially all nationalist publications" assumed a friendly attitude towards Nazi Germany, with Crisol Osés "surpassed all his colleagues" (Buchrucker 1982: 295); he never hid his respect for Hitler, and repeatedly hailed him as a role model. Reacting to the "Night of the Long Knives" in mid-1934, which had culminated in the assassination of the Fuhrer's opponents, in an editorial titled "Heil Hitler!" the self-declared "National Socialist" (Zuleta Alvarez 1975: 286) unreservedly defended the events. Osés stated that in

En Hitler se ataca el triunfo paulatino, pero seguro, de un régimen de afirmación nacionalista, que trueca todos los valores falsos, todos los falsos ídolos antes adorados. En Hitler se ataca al hombre que representa, indiscutiblemente, un anhelo de superación del siglo que aún lleva a cuestas los fardos del pasado. En Hitler se combate todo ese ejemplo de esperanzas que hace vibrar a los pueblos hoy, desengañados de la democracia política, del capitalismo judío, de la anarquía social, de la libertad...para que la gocen unos cuantos cientos o miles de privilegiados. ${ }^{38}$

Osés's paper, which described itself in the local organ of the German Nazi party, the Mitteilungsblatt der Nationalsozialistischen Deutschen Arbeiterpartei-Landesgruppe Argentinien (as of 1934 named Der Trommler), as the "only Argentine daily that openly and honestly speaks up for Hitler's Germany" (Ebel 1971: 90, n. 40), praised Mussolini and Italian Fascism in a similar way (Buchrucker 1982: 265). After the outbreak of the Spanish Civil War in July 1936, which lastingly polarised the country in general and the intellectual field in particular between supporters of the Spanish Republic and the defenders of the nationalist Insurrectionists (Falcoff 1982; Trifone / Svarzman 1993), Francisco Franco received the same favourable treatment as the two fascist dictators. Osés supported his cause through Crisol. Together with other prominent Nacionalistas, namely Manuel Gálvez, Delfina Bunge de Gálvez, Carlos and Federico Ibarguren, he also joined the pro-Franco group Socorro Blanco Argentina pro Reconstrucción de España (Quijada 1991: 29 and 179), set up "to gather funds to help Nationalist Spain confront "the diabolic forces of Communism"” (Falcoff 1982: 313).

and himself no friend of Jews, rejected these suggestions as too radical (Senkman 1991: 130). For Franceschi's attitude towards Jews, see Metz (1993). For a general discussion of the anti-Semitism of the nacionalista movement during the period under consideration, see Lvovich (2001; 2003: 237-371). 
In the ideologically charged atmosphere of the 1930s the "profound sympathy for the German Nazis and the Italian Fascists", ${ }^{39}$ which Osés's paper repeatedly expressed, led to accusations that the European fascists financially supported Crisol in particular and the nacionalista movement in general. Crisol vehemently rejected these attacks. It averred that Hitler and Mussolini did not interfere in Argentine affairs - unlike Stalin, who "is stirring up all the enemies [of] the fatherland." 40 Yet, notwithstanding these claims, the paper did in fact benefit from German as well as Italian support. Just as the other leading nacionalista daily, Juan Carulla's Bandera Argentina, Osés's paper regularly received articles of the Hamburg-based Aufklärungsausschuss, a subsidiary organisation of Joseph Goebbels's ministry of popular enlightenment and propaganda that prepared articles in which the National Socialist ideology and German politics were explained and defended, as well as wires of the German news agency Transocean. They were delivered free of charge, but Osés, who personally received them, did not get paid for publishing these predominantly anti-Communist and anti-Semitic articles in Crisol (Müller 1997: 263-265 and 276). ${ }^{41}$ In addition to articles, the Italian Embassy also granted "small subsidies" (Zanatta 1996: 284).

As far as the Germans were concerned, the main reason for the sparing support of Crisol was its limited influence on Argentine public opinion. The German Embassy appreciated the daily's outspoken defence of the Third Reich's policies, as for example in the aftermath of the Anschluss of Austria in March 1938. ${ }^{42}$ At the same time, however, it did not fail to stress its insufficient scope and relevance (Ebel 1971: 343). This interference also applied to other pro-German nacionalista papers, such as Bandera Argentina, and the nacionalista movement in general. ${ }^{43}$ After reaching its peak during Uriburu's short-lived revolutionary regime, the number of militants organised in the various factions -in October 1933, Wilhelm Lütge, a representative of the German Legation in Buenos Aires, estimated that approximately thirty different groups were active- declined sharply. ${ }^{44}$ Personal enmities, the lack of a generally accepted leader, and programmatic differences meant that, from the point of the view of the Nacionalistas, the situation did not improve during the

39 Crisol, 28 June 1935: 1.

40 Crisol 28 June 1935: 1 and 4.

41 During the first 18 days of January 1935 Crisol published, for instance, 19 articles of the Aufklärungsausschuss and between 1 November 1938 and 31 March 193964 articles. See Müller (1997: 266) and Ebel (1971: 90, n. 40), respectively.

42 Politisches Archiv des Auswärtigen Amtes, Bonn/Berlin (PA AA) (1938).

43 See PA AA (1933); (1935); (1936).

44 Wiener Library (1933). 
course of the 1930s. Crisol's weakness reflected, then, only the generally feeble state of the self-declared saviours of the Argentine nation.

Osés was partly responsible for this situation; his radicalism alienated a potential ally in his struggle against the liberal order and communism, the Catholic Church, which exercised considerable influence on important sectors of Nacionalismo during the 1930s. Because of his open and outspoken admiration of European fascism, which implied the defence of a totalitarian regime in Argentina that would put an end to "the absurd and insidious liberal division of the Three Powers", ${ }^{45}$ the Argentine hierarchy "distanced itself from Osés and his position since 1935" (Ben-Dror 1996: 130, n. 85; see also 2003: 153154). His commitment to the introduction of "Catholic and nationalist" curricula at all levels of the education system, ${ }^{46}$ and the protestations that "the Church constitutes the soul of the Nation" and that the nacionalista movement did "not want to succeed, nor rule, nor reign without Christ", ${ }^{47}$ counted for little. Crisol's comments about the role of the Church in the new nacionalista order indicated in fact that Osés now embraced a position that he had attacked as editor of Criterio, namely the primacy of politics. ${ }^{48}$

His lack of political vision and intransigence also weakened Nacionalismo. Throughout the decade the editor of Crisol did not set out, for example, how the movement -"this force that [was] still divided into factions and legions" could be united. Moreover, until the late 1930s Osés never joined any group, nor did he make any serious efforts to establish his own faction, nor did he actively seek the unification of the different nacionalista organisations under one leadership, not even his own. ${ }^{50}$ Rather, while deploring the lack of a unifying figure, he torpedoed attempts to find a generally accepted leader after the death of Uriburu in April 1932. ${ }^{51}$ When Juan Bautista Molina, a close collaborator of Uriburu, the driving force behind the establishment of the Civic Legion, and a leading Nacionalista within the armed forces, was named as a possible contender, he rejected him. Osés argued that his position as an active military officer ruled him out for this role. ${ }^{52}$ His objection to Molina's repeated attempts to assume power by means of a military coup (Buchrucker 1982:

\footnotetext{
45 Crisol 15 April 1936: 3.

46 Crisol 18 Oct. 1936: 3.

47 Crisol 29 March 1935: 1.

48 Crisol 15 April 1936: 3.

49 Crisol 6 Jan. 1936: 1.

50 In the 1930s Osés only enjoyed the unconditional support of the Asociación de Amigos de Crisol, an organisation that defined the dissemination of the paper as its main aim. Crisol 19 April 1936: 1.

51 Osés (1936: 34-35).

52 Crisol 28 Dec. 1933: 1.
} 
304-305) only increased the enmity between the two prominent Nacionalistas; these personal animosities would haunt the movement until the early-1940s, complicating any effort to reach an understanding within the more extreme sectors of Nacionalismo.

In addition, Osés never convincingly expounded how the estranged movement should assume power. For the editor of Crisol, the formation of a party, and the direct participation in the electoral process, was not a viable option. He denounced those nacionalista groups that (unsuccessfully) nominated candidates for national elections, for instance José María Rosa's Nacionalismo Laborista, as bad imitations of political parties that had nothing to do with the movement. ${ }^{53}$ Expressing an attitude shared by the overwhelming majority of Nacionalistas, he endorsed the blank vote instead. Osés argued that

El Nacionalismo, votando en blanco, mata dos pájaros de un tiro. Rechaza los fórmulas que se le presentan, por contrarias al bienestar moral y material y al porvenir de la República. Y certifica una vez más, que los nacionalistas estamos de vuelta de toda la farsa democrática con que se sigue embaucando a los argentinos sin nada en la cabeza y en el corazón, y que no se puede contar con nosotros, para una mentira más, de la que el único perjudicado, el único pato de la boda, será el pueblo, al final de las cuentas de siempre. ${ }^{54}$

His explanations notwithstanding, it remained unclear why this practice furthered the interests of the movement. Given the declining number of militants, it was highly unlikely that the few blank votes cast by Nacionalistas could lastingly have undermined the legitimacy of the conservative regime. Nor could the modest results be presented as a propagandistic victory. ${ }^{55}$

On the eve of the Second World War Osés's position within the nacionalista camp was, then, not as dominating as some of his followers subsequently claimed. As the editor of the most radical nacionalista daily he certainly influenced some sectors of the movement, but it was not "decisively directed" by him (Samyn Ducó 1978: 62). Tellingly, he did not play any role in the foundation of the Alianza de la Juventud Nacionalista (AJN), an offspring of the Civic Legion's youth organisation that, set up in September 1937, developed into the strongest faction of the late 1930s and early 1940s (Klein 2001). The establish-

53 Crisol 6 Jan. 1935: 1. In 1936 Nacionalismo Laborista nominated candidates for the elections to the Chamber of Deputies in the Federal Capital, receiving 1,681 votes $(0,10 \%$ of the total national vote, or $0,46 \%$ of the votes cast in the city of Buenos Aires). See Cantón (1968: 115-116). Juan Carulla and Bandera Argentina endorsed Rosa, and they therefore also incurred Osés's wrath. See the editorial in Crisol 1 Jan. 1935: 1. Osés (1937: 18).

55 I would like to thank Federico Finchelstein for making this point. 
ment of El Pampero in November 1939 would change this situation, albeit only partly. With a circulation of 50,000 three years after its foundation, it clearly overshadowed all other nacionalista publications. ${ }^{56}$ Because of its strength Osés, who remained owner of $\mathrm{Crisol}$, had an unprecedented platform for the realisation of his personal aspirations that he began to formulate more forcefully. At the same time, his outspoken support of Nazi Germany's war aims and the welldocumented collaboration with the Third Reich, which bankrolled the paper, undermined his standing and branded him as one of the leading public enemies.

\section{In the Service of the Anti-Argentine Propaganda}

Although Osés officially signed as the founder of El Pampero, and assumed its editorship, the decision to set up the paper was taken in Berlin soon after the outbreak of the war. Reacting to its diplomats' earlier complaints about the inefficiency of the presentation of German interests in the media and the predominantly anti-German and pro-British attitude of the public as well as the country's opinion leaders after Britain's and France's declaration of war (Newton 1992: 222-223), the Auswärtiges Amt, which had taken over the responsibility for the foreign propaganda of the Third Reich from the ministry of popular enlightenment and propaganda in September 1939, took the initiative. It would no longer rely on the articles the Aufklärungsausschuss and Transocean had provided for years to "second-class papers", not least Crisol. It launched its own daily. Using "considerable funds", El Pampero appeared on the newsstands in early November 1939 (Müller 1997: 273). ${ }^{57}$

Not surprisingly, over the next years the German Embassy in Buenos Aires did not fail to single out the publication as the only "representative of our

56 Navarro Gerassi (1968: 155) states, El Pampero reached a circulation of 75,000 in the early 1940s. Bandera Argentina was the second strongest paper with 7,000 copies; Crisol only printed 4,000 copies at the time. Although Navarro Gerassi does not indicate her source -she only refers to the findings of the Chamber of Deputies' Comisión Especial Investigadora de Actividades Antiargentinas-, she seems to rely on documents that can be found in Archivo Político de la Cámara de Diputados, Comisión Especial Investigadora de Actividades Antiargentinas, Buenos Aires (APCD/CEIAA) (n/d a). These carbon copies have to be treated with some caution, as they do not contain any information about the author, nor the date and the place of publication. For circulation of $E l$ Pampero, see PA AA (1942d): R 29543, Embassy to Auswärtiges Amt, Buenos Aires, 5 Nov. Only surpassed by the 66,000 copies printed on the occasion of its third anniversary, this is the highest regular circulation mentioned in the reports of the Embassy.

57 Frank described "The bond between El Pampero and the Nazi Embassy...like that between infant and mother" (1944: 128). 
interests" in Argentina. Since the most influential papers, particularly $L a$ Nación, La Prensa, and El Mundo, were "completely inaccessible, not even for millions (Millionenbeträge)", ${ }^{8}$ the survival of Osés's publication was guaranteed with all possible means. The shortage of paper, a problem that particularly troubled the Embassy and threatened to finish the enterprise, was resolved through the spending of increasing amounts of money. ${ }^{59}$ The "abundant advertising" of German firms, for example by Messerschmitt, BMW, Rheinmetall, and Zeiss-Ikon (Rouquié (1981: 297, n. 13), also helped to keep the daily alive. Reflecting its importance for the Germans, even after the Comisión Especial Investigadora de Actividades Antiargentinas of the Chamber of Deputies had revealed the financial support of Berlin for El Pampero in September 1941 and described it as "the paper in the service of the anti-Argentine propaganda" ${ }^{60}$ the diplomatic representation of the Third Reich doubled its efforts. It took measures to establish a printery for the newspaper. ${ }^{61}$

From the point of view of the German diplomats as well as the officials at the Auswärtiges Amt the money was obviously well spent. The circulation rose, slowly but steadily, and favourably compared with the other nacionalista papers; El Pampero almost produced as many copies as the smaller mainstream dailies, for instance the morning paper El Diario $(80,000)$ and the evening paper La Razón $(81,000)$ (Heide 1940: col. 247). Even more important was however that with its "violent and personal attacks" the paper went "far to influence public opinion", as the British Embassy, which denounced the German investments in the publication as early as January 1940, grudgingly conceded. ${ }^{62}$ Thus, while El Pampero may have been "the most scurrilous paper on this side of the Atlantic", as one contemporary stated, it was also an effective one. ${ }^{63}$

58 PAAA (1940).

59 PA AA (1942a); (1942e).

60 Cámara de Diputados (1941: 657). Heinrich Volberg, who played a well-known and crucial role in bankrolling the paper through the Oficina de Fomento del Comercio Alemán, a subsidiary organisation of the German Embassy, subsequently stated that the figures indicated by the Commission were too low (Volbert 1981: 141). Unfortunately he did not state how much money El Pampero actually received.

61 PA AA (1942e).

62 Public Record Office, Foreign Office, London (PRO/FO) (1940b). For denunciation, see PRO/FO (1940a).

63 El Pampero would soon hold "the record for all Argentine papers in suspensions by the government" (Loewenstein 1943: 1270, n. 22); by 1942 it had "been sued fifty-eight times for libel, calumny, contempt, [and] extortion"; and Osés was repeatedly arrested for obscenity, as for example in July 1940, "for printing an acrostic lampoon of Winston Churchill; the first letters of each line combined to read 'One must be English to be a son of a whore"' (Riesman 1942: 1122, n. 175). 
Osés deserved the credit for these questionable achievements. In the virulently anti-Semitic admirer of Hitler and restless defender of the Axis the Germans had a willing, able, and reliable collaborator who presented their views, which he wholeheartedly shared, aggressively and uncompromisingly. Employing Nazi-style vocabulary, El Pampero, the self-declared "arch-Creole" newspaper (Rouquié 1981: 297), did not grow weary of justifying Germany's war of aggression. A few days after the invasion of the Soviet Union in June 1941, for instance, an article praised Hitler as the saviour of "Christian civilisation". It maintained, "only one clear, single truth arises from this new and colossal aspect of the European war":

El gesto enorme de Hitler de acometer la Rusia comunista, después de haber procurado, por todos los medios, contener a la Bestia roja en sus intenciones de subyugamiento ( $\mathrm{sic}$ ) de Europa....Rusia, el anticristo, será derrotado por Europa. E Hitler, el Fuhrer del Tercer Reich, es el genio, que en el momento más crítico de la historia de Occidente, gana para su Nación, una vez más la gloría que nadie podrá quitarle en adelante: de haber salvado la civilización cristiana, que es la nuestra, a la que no podemos renunciar sin renegar de nosotros mismos. ${ }^{64}$

Joyous reports on the victories and advances of Germany and Japan on the one hand, and gloating articles about the putative retreats and defeats of the Allies on the other, further underlined the sympathies of the paper. ${ }^{65}$

The constant attacks on the two western democracies, and increasingly the USA, was another aspect of El Pampero's role as the "official Argentine spokesman for the Axis in foreign policy” (Rennie 1945: 277). Osés asserted that Britain, "H[er] M[ajesty] the Robbery", was not fighting for Argentina, as its sympathisers tirelessly stated. It only fought "[f]or the survival of the regime of democratic oppression that it has imposed on the world". ${ }^{66}$ The United States and President Franklin D. Roosevelt, the "paralytic and megalomaniac slave of the Jews", ${ }^{67}$ were treated with no less contempt. The Good Neighbour policy, with its appeal to the common interests of the liberal democracies and "continental unity", was denounced as a means of "the democratic imperialism of North America" to secure its domination of South America in general and Argentina in particular. ${ }^{68}$ The underlying objective was, Osés maintained, the replacement of Britain as "the hegemonic power in the Argentine." 69 These

\footnotetext{
64 El Pampero 26 June 1941: 9.

65 El Pampero 28 Dec. 1941: 1-3.

66 Osés (1941b: 47).

67 Osés (1941a: 3 and 2). The booklet partly reproduced three speeches Osés had given in San Rafael, San Juan, and Mendoza, published in Crisol on 1 May 1941.

68

Osés (1941b: 35).
} 
attacks on the USA and the "criminal war-mongering' of Mr. Roosevelt...had", as the British Embassy conceded, "some effect, with the result that the open partisanship of the United States while increasing belief in our ultimate victory, has probably not increased sympathy with our cause."70

At least as far as the impact on the overwhelmingly pro-British attitude of the Argentine population was concerned, Osés, if he had been aware of this assessment by one of his archenemies, would have been pleased with himself. At the same time, he must have realised however that Britain's overall position $v i s-\grave{a}$-vis the Third Reich did indeed improve because of the alliance with Washington; and this development certainly did not find his approval. Probably more than any other Nacionalista, the editor of El Pampero hoped for a victory of the Axis, as its triumph would have vindicated his collaboration with the Third Reich. The impassioned defence of Hitler's Germany even overshadowed his public support of Argentina's neutrality in the conflict, a position officially adopted by the Argentine government immediately after the outbreak of the war and widely supported by the nacionalista movement. ${ }^{71}$ As against the majority of his fellow Nacionalistas, not least the Alianza of Juan Queraltó, Osés was certainly more inclined towards the Axis (Navarro Gerassi 1968: 140-141).

Because of his blatantly pro-Nazi attitude, leftist members of parliament repeatedly, albeit unsuccessfully, called for the definite closure of El Pampero, for instance in the (Argentine) winter of $1942 .{ }^{72}$ Yet, some Nacionalistas also strongly objected to his open admiration of the fascist dictators. They denounced the editor of the leading nacionalista paper as the prolonged arm of foreign interests in the country. Guillermo Carrizo, a representative of the Irazusta brothers and Palacio's Partido Libertador in Córdoba, stated for example that Osés's views were both anti-democratic and anti-Argentine, and "a dangerous deviation, not only ideologically but also morally" (as quoted in Piñeiro 1997: 193). In the same vein, Rodolfo Irazusta had Osés in mind when he stated that those who "excessively admire Hitler, Mussolini or Franco, and even admit the significance of their respective movements in our land", could not claim to be Nacionalistas. In order to be successful, the movement had to achieve "total autonomy" from "foreign nationalists". ${ }^{73}$

69 Osés (1941a: 2).

70 PRO/FO (1941a).

71 A notable exception was the journal Nuevo Orden, edited by Rodolfo and Julio Irazusta as well as Ernesto Palacio, which rejected this position, arguing that it only favoured Great Britain. See, for instance, Irazusta (1993: 161 and 164), originally published in Nuevo Orden, 25 March 1942.

72 PA AA (1942b).

73 Irazusta (1993: 161 and 163). The statements had originally been published in Nuevo Orden, 25 March 1942. 
As far as Irazusta was concerned, Osés's ideational closeness to the European dictators, and sympathies for them, were not his only sins. He also criticised his lack of political vision; the formation of a political party and the participation in the electoral process was still not a feasible option for the editor of El Pampero. Repeating earlier statements, he asserted, "the nacionalista conscience" "rejected the current electoral regime as a means of [its] struggle, as a tool for the attainment of [its] objectives", because they were "one of the main reasons for the sufferings" of the nation. ${ }^{74}$ For Osés, who stated with some justification that the "immense majority of Nacionalistas" shared his position, it was the "conservatism" of the Irazustas, who advocated the "gradual conquest of electoral positions", that amounted to a sell-out to the traditional oligarchy. ${ }^{75}$ In accordance with this position, when the Partido Libertador (unsuccessfully) nominated candidates for the provincial election in Entre Ríos in March 1943, an acrimonious confrontation between its and Osés's followers, who endorsed the blank vote, characterised the election campaign. ${ }^{76}$

At the same time, Osés also voiced his opposition to another putsch that Molina, the de facto leader of the Alianza, advocated and repeatedly, albeit with success, attempted (Potash 1969: 149-152; Rouquié 1981: 324-325). Alluding to the "Revolution of 1930", Osés described this nacionalista current as "septembrismo" 77 or as "the old molinista trend." 78 While being close to "the true nature (lo esencial)" of Nacionalismo, it pursued an equally misguided strategy ${ }^{79}$ it distracted the energy of the Argentine youth from "the arduous, slow and sacrificing nacionalista objective" of establishing Nacionalismo "as a national expression, as a collective opinion, as a patriotic vote", as a "Movement of souls." ${ }^{\prime \prime 0}$ Moreover, it wanted to carry out the "revolutionary coup' even with the...men... of September" 1930, ignoring that the situation had fundamentally changed since the days of Uriburu. They "made September", passed the period of "institutional normality" and now spent "the present time in their positions. Yet, they have not got in touch with reality. They have not worked out the meaning -unknown to them- of Nacionalismo." 81

\footnotetext{
74 Osés (1941b: 58).

75 Osés (1941b: 61 and 74).

76 The Partido Libertador received 1,148 votes, and the supporters of the blank vote 1,929. Together the two factions obtained less than one per cent of the overall vote. For a discussion of the party, Piñeiro (1997: 184-204).

77 Osés (1941b: 73).

78 APCD/CEIAA (1941a).

79 Osés (1941b: 73).

80 Osés (1941b: 49 and 57).

81 Osés (1941b: 48 and 84).
} 
As against the Irazusta brothers, Molina, as well as Fresco, who "aspired to form a bridge between conservatism and Nacionalismo" and therefore incurred Osés's hatred (Dolkart 1993: 84), the self-declared "First Comrade"82 knew the true meaning of the movement and the desires of its followers. The Nacionalistas wanted, above all, to bring together the varying factions. ${ }^{83}$ In view of this fundamental necessity, which would create the prerequisites for the emergence of a truly "National Movement", the decision about the appropriate means to achieve power was of secondary importance, Osés asserted. Only after the Nacionalistas had won over the majority of the population they would make up their minds. Then, they would decide whether they participated in the electoral process or staged a coup, or took any other unspecified measure that guaranteed the realisation of their dream: ${ }^{84}$ a totalitarian regime that, based on corporatist representation, would "direct and co-ordinate" the different "economic interests" and bring about social justice and harmony between the classes, replacing the "false", "anti-natural", and "anti-Christian" "myths of free-trade liberalism, free and all-embracing private initiative, [and] individual liberty" that were in mortal decline. ${ }^{85}$

This discussion within the nacionalista movement about the correct strategy was, as Osés's personal attacks and his self-portrayal as the "First Comrade" indicated, ultimately one about power. Seconded by El Pampero, Osés increasingly styled himself as the man who was destined to unite "all the nacionalista aspirations." ${ }^{" 86}$ And "although [he did] appear as the top leader of Nacionalismo, the reality [was] different." ${ }^{\text {87 }}$ Osés only found vocal support in the Interior, especially in the provinces of Santa Fe and Mendoza. ${ }^{88}$ There the Unión Nacionalista $a^{89}$ praised him as "our Caudillo" 90 and "the leader (conductor) of the new Argentina that arises without politicians and without Jews but

82 El Pampero 2 May 1942: 1.

83 Osés (1941b: 74).

84 Osés (1941b: 60-61).

85 Osés 1(941a: 8-10 and 12).

86 Osés (1941b: 61).

87 APCD/CEIAA (1940b). This assessment is also corroborated by the fact that Osés did not belong to either the Consejo Superior del Nacionalismo or the Congreso de la Recuperación Nacional, two failed attempts to set up umbrella organisations of the nacionalista movement in the early 1940s. For members, see Navarro Gerassi (1968: 156-157, n. 19-20).

88 APCD/CEIAA (1940a); (1942b).

89 It was not possible to ascertain the exact date of the group's foundation. A Unión Nacionalista Argentina de Rosario existed at least as early as late 1934. Crisol 1 Jan. 1935: 1, reproducing a speech Osés gave at a meeting of the group. At the time, the faction did not play a significant role in nacionalista politics. 
with social justice." ${ }^{91}$ Both Molina and Fresco, who made some significant inroads into the nacionalista camp despite Osés's and the Alianza's consistent attacks (Klein 2001: 114), were undoubtedly more successful. Molina, celebrated as the "Supreme Chief" by the $\mathrm{AJN}^{92}$, and Fresco, the leader of PatriaUnión Nacional Argentina and "close friend and political supporter" of acting President Ramón Castillo, ${ }^{93}$ enjoyed a considerably greater following than Osés amongst the relatively small number of Nacionalistas (Klein 2001: 115116). The Alliance and the National Union dominated nacionalista politics in the city and in the province of Buenos Aires, the centres of the movement's activities in the early 1940s. The Irazusta brothers, on the other hand, only played only a minor role. Their electoral strategy did not meet with good response.

Although Osés never officially relinquished his claim to be the "First Comarade", in the end he it was who had to rethink his position. By the late (Argentine) summer of 1941 Osés had accepted that, in view of the weak popular support of the movement and the bleak prospects of changing this situation in the foreseeable future, the formation of a truly "National Movement" along the lines outlined by him was no longer a feasible option; the attempt to broaden the appeal of Nacionalismo by "going to the people" 94 -a renunciation of his previous élitism and anti-popular attitude- and to emerge as the undisputed leader of this unified movement had failed. Overcoming his earlier reservations, which reflected his concern that the collaboration with the armed forces would invariably lead to the marginalisation of the civilian nacionalista groups, repeating the experience of the revolution of $1930,{ }^{95}$ El Pampero made "common cause with the military nationalists" (Rouquié 1981: 310).

The co-operation with this sector, which shared the civilian Nacionalistas' anti-political, anti-democratic, anti-oligarchic, and pro-neutral convictions, went hand in hand with a rapprochement between Osés and the Alianza, the group that for some time had focused its energies on winning new adherents within the armed forces. ${ }^{96}$ His presence at the rally organised by the AJN on Labour Day 1942, an event that on earlier occasions El Pampero had only benevolently announced and commented on, underlined the newly achieved amity. ${ }^{97}$ Yet, in spite of the positive echo his appearance had, not least on the

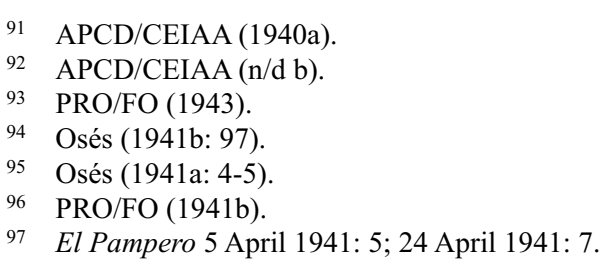


part of the Alianzistas, this was "an alliance without major commitments of either sides." 98 The "Supreme Chief" and the "First Comrade", reflecting their deep-seated animosities, could not reach an agreement concerning the leadership of a unified faction, and therefore the collaboration was never formally established. ${ }^{99}$

According to Osés, the attempt "to unite his forces with those of General Molina in the mass meeting held on 1 May" was not the result of "the pressure exerted by the military". Ramón Castillo it had been who had asked him to participate in a rally that explicitly endorsed his policy of neutrality. ${ }^{100}$ The acting president, an unrepentant conservative of the old school who resisted the pressure of the United States to break off the diplomatic relations with the Axis and therefore enjoyed the goodwill of the Third Reich ${ }^{101}$ as well as the Alianza (Klein 2001: 112-113), had also assured him of his sympathies for "the cause that he represented", the "First Comrade" declared in front of his followers. Since "the whole country knew", however, "that the paper he directed" was "totalitarian", Castillo told him during a meeting, he "could not use him". If he had to rely on a movement, it would be the Unión Nacional Argentina of Manuel Fresco, who had organised his own rally on Labour Day in support of the government and Argentine neutrality. ${ }^{102}$

Osés's account of events was not as implausible as it might seem. Castillo, while always trying to keep the nacionalista groups in check, also carefully cultivated them; he particularly hoped to gain the goodwill of their sympathisers within the armed forces (Senkman 1995: 36-37). Castillo maintained close contacts with Fresco and was in touch with Molina. His administration's restrained attitude vis-à-vis El Pampero fitted into the same pattern. In spite of its well-document relationship with the German regime, the federal authorities never took any decisive measures against the most important nacionalista daily, or his editor. When, for example, the minister of the interior, Miguel J. Culaciati, suspended the paper in February 1943, its links with the Third Reich were not an issue. ${ }^{103}$ Equally telling was that Castillo lifted the closure of the

98 APCD/CEIAA (1942a). The reactions of the militants of the Unión Nacionalista Santafecina were more ambiguous. The majority supported the co-operation but a group around Juan Lo Celso, the provincial leader of the faction, left in protest, joining forces with Fresco. See Archivo General de la Nación, Fondo Documental Presidente Agustín P. Justo, Buenos Aires (AGN/FDJ) (n/d).

99 AGN/FDJ (1942).

100 AGN/FDJ (1942).

101 PA AA (1942c).

102 AGN/FDJ (1942).

103 The decree only referred to "the discourteous insults" against the "great men" of Argentine history, particularly Domingo F. Sarmiento and Bartolomé Mitre. El Pampero had 
daily, which had originally been suspended for an undetermined period of time, after a few days. ${ }^{104}$

As the political developments showed soon after the last suspension of $E l$ Pampero, the collaboration between the president and the Nacionalistas in general and Osés in particular proved to be conditional and short-lived. When the armed forces, "tired of election fraud and the air of scandal and racketeering that pervaded this government", deposed Castillo on 4 June 1943 and thereby prevented the election of his handpicked successor, Robustiano Patrón Costas, "the most powerful of the Tucumán sugar barons" who "was reputed to favor the Allies, and especially the British" (Rock 1987: 247), the Nacionalistas showed no compassion for him. They did not rally to his support. Rather, they warmly welcomed the self-declared saviours of the nation, celebrating the end of the traditional oligarchy's dominance over Argentine politics and hoping for the establishment of a new order under their leadership. Typical of their reaction, "in a triumphant editorial" El Pampero even "declared that a fascist regime at long last had been established in Argentina" (Loewenstein 1943: 1306).

During the first couple of months Osés and his fellow Nacionalistas had every reason to be content; the new rulers suppressed communist and democratic activities and preserved Argentina's neutrality. After the nacionalista faction within the armed forces had gained the upper hand over a more moderate current, which favoured the accommodation of the United States, in the (Argentine) spring of 1943 a series of policy measures were carried out that raised the enthusiasm of the civilian supporters even further. On two consecutive days in early January 1944, all political parties were dissolved and Catholic religious education was introduced into the curricula of state schools. El Pampero, which had already stated that the adoption of the first decision "had comforted and consolidated the belief in the revolution", equally warmly welcomed the second decree. Finally, "the young generations of Argentines, today disturbed and disorientated by the... atheistic and unpatriotic education that the state imparts in the compulsory schools" in the general and the children of "heretics, Jews and Muslims" in particular would benefit from the reaffirmation of the Christian and Western concepts of the nation. ${ }^{105}$

attacked them as part of its revisionist effort to denigrate the traditional oligarchy and the liberal hegemony on the one hand, and to vindicate Juan Manuel de Rosas, the 19thcentury dictator, on the other (Quattrocchi-Woisson 1995: 217).

104 The interview he had granted El Pampero a few weeks earlier, in November 1942, could be interpreted as another example of Castillo's cautiously benevolent position vis-à-vis the Nacionalistas. At the time, the paper's financial support by the Third Reich had long been revealed. See PA AA (1942e).

El Pampero 2/3 Jan. 1944, as quoted in Piñeiro (1997: 250). 
As it turned out, this was the last occasion for El Pampero to celebrate. The dissolution of all nacionalista groups and the rupture of diplomatic relations with the Axis powers in late January 1944, a consequence of the increased pressure of the USA, soon shattered its professed "belief in the revolution". Osés's warning concerning the marginalisation of the civilian Nacionalistas in a military regime turned out to be correct. "The Nacionalistas cried out against the betrayal" and their leading daily "virulently criticised the president", but to no avail (Rouquié 1982: 44). The only tangible result of their outspoken protests was the closure of El Pampero. And although the paper reappeared within a few weeks as El Federal - "with the same editor, the same format, the same office, and the same mailing permit"106 - the career of "the fanatical Nazi, Señor Osés," was drawing to a well-deserved close. With the new publication Osés faced his last struggle for a lost cause. ${ }^{107}$

\section{The Last Struggle}

Just as El Pampero, so El Federal still presented the war news "entirely in favour of the Axis" and was "anti everything Russian, British and American." 108 If only in the paper, which uncritically reproduced the propaganda coming from Berlin, the Third Reich was not retreating on all fronts but advancing throughout Europe. In complete disregard of the developments in the European theatre, in April 1944 Osés's new paper asserted for instance that Germany was still going to win the war; its soldiers, the chief propagandist of German Nazism in Argentina asserted, were more dedicated and had a higher morale than those of the Allies. ${ }^{109}$ Even more revealing was that El Federal did not simply praise the Wehrmacht and defend the imperialist war of the Fuhrer; the publication unreservedly identified itself with Hitler, the Third Reich, and its armies, referring to the German troops as "our formations" and the Allies' ones as its enemies. ${ }^{110}$

This outspoken defence of Nazi Germany also overshadowed Osés's and $E l$ Federal's enthusiastic support of Juan Domingo Perón. Unlike the majority of Nacionalistas, who viewed Perón pro-labour policies with some apprehension, but in accordance with Queraltó's Alianza (Klein 2001: 118) and Osés's own populist and anti-oligarchic positions, El Federal commented every single act

\footnotetext{
106 United States of America (1946: 37).

107 PRO/FO (1944).

108 PRO/FO (1944).

109 El Federal 19 April 1944: 8.

110 El Federal 9 April 1944: 8.
} 
and public appearance of Perón in positive terms. ${ }^{111}$ In late November 1944, on the occasion of the first anniversary of the foundation of the labour secretariat, which Perón used for the realisation of his social reforms (as well as the basis for increasing his political power), the paper was full of praise for his achievements. Moreover, it did not fail to single him out from his colleagues in the regime. Perón it was, El Federal tirelessly maintained, who deserved the credit for having curtailed the power of international capitalism and the old oligarchy. ${ }^{112}$

While Perón was only at the start of his political career, Osés's had reached its end when El Federal published this article in late November 1944. At the time Osés must have realised that he was a man of the past. The future belonged to other people, those who were not as compromised as he was, a collaborator of the Third Reich and an apologist of its war of extermination. Whatever his paper wrote about Nazi Germany's strength and the Allies' weaknesses, fascism was about to loose the confrontation against the joined forces of its declared enemies -the liberal democracies of the United Stated and Great Britain on the one hand, and the communist regime of the Soviet Union on the other. It was no longer the force of the future, as Osés and other fascists had stated since the early 1930s; its opponents in this epochal confrontation were defeating it. His lifework in shatters, one of the leading Nacionalistas finally retired from public life.

\section{Final Remarks}

The reactions of Osés's numerous opponents to his decision are not known, but one may safely assume that they received the news with relief and satisfaction, as one of the most unpleasant activists of the nacionalista movement, who had tormented his countless victims with relentless diatribes and vitriolic attacks, finally disappeared from the political scene. During his relatively short journalistic and political career Osés had primarily distinguished himself by stirring up hatred against, as he saw it, the enemies of the Argentine nation: liberals, conservatives, leftists, Jews, and even some of his fellow Nacionalistas, namely those who rejected his collaboration with the Third Reich and/or did not accept his claims to leadership. Without ignoring his many obvious shortcomings, and his failure clearly to define the appropriate means for and objectives of the nacionalista movement, it would be misleading to state that Osés did not give Nacionalismo its "own political character" and that he had no political vision

\footnotetext{
111 El Federal 30 April 1944: 5.

112 El Federal 27 Nov. 1944: 2.
} 
(Zuleta Alvarez 1975: 291), however. He might not have been very convincing, and he certainly was not-like all other Nacionalistas-successful, but Osés did in fact articulate his own vision of a totalitarian regime.

By the late 1930s, after he had distanced himself from his earlier elitist and anti-popular attitude, the self-declared "First Comrade" of the nacionalista movement and admirer of the European dictators can be described as a fascist. Not because of his radical anti-Semitism and vocal support of both Hitler and Mussolini (Buchrucker 1982: 336), but because his ideas were based on a "revolutionary form of ultra-nationalism" that was characteristic of all fascist movements (Griffin 2001: 48). Just as his fascist counterparts in Europe, so Osés preached "the need for social rebirth" of the nation to reverse its alleged decline and bring about an era of national greatness. Osés proclaimed that he aimed at the establishment of a new totalitarian order that would transcend liberal capitalism and communist statism, overcoming the divisions created by political parties and reuniting all social sectors and classes in a hierarchically organised national community (Eatwell 1996: 11). He displayed, moreover, other features that are commonly described as defining characteristics of European fascism, particularly a "vitalist philosophy", an extreme élitism, the Führerprinzip, the positive valuation of "violence as end as well as means" and the trend "to normalize war and/or military virtues" (Payne 1995: 14).

Between the start of his career in Criterio in the late 1920s and early 1930s and his retreat into obscurity in late 1944, Osés's worldview changed in many important ways, hence. While he rejected democracy since his days at the Catholic magazine, after taking over the nacionalista daily Crisol the erstwhile defender of the Catholic Church and critic of European fascism emerged as an outspoken admirer of the European dictators and a proponent of a totalitarian regime in the Argentine. His growing admiration of the Third Reich culminated in the open collaboration with Nazi Germany in the late 1930s and early 1940s. The establishment of El Pampero was, then, the peak as well as the low in his career. On the one hand, it offered him an unmatched platform for the pursuit of his own political aspirations. On the other, however, the well-known relations with the regime of Hitler also undermined his standing. Osés was caught in a vicious circle. Only the victory of the Axis in the Second World War could possibly have changed this situation. Fortunately, this never happened.

\section{Bibliography and References}

Archivo General de la Nación, Fondo Documental Presidente Agustín P. Justo (AGN/ FDJ) (Buenos Aires) (n/d): Caja 104, "Política nacional (1942)", document n/no, "Centros nacionalistas". 
- (1942): Caja 104, "Política nacional (1942)”, document 149, "Síntesis del movimiento nacionalista hasta 21/7/942".

Archivo Político de la Cámara de Diputados, Comisión Especial Investigadora de Actividades Antiargentinas, Buenos Aires (APCD/CEIAA) (n/d a): Legajo 13, cuerpo 2, "Nacionalismo 1", sheets 204-211.

- (n/d b): Legajo 12, cuerpo 2, "Provincia de Santa Fe", sheet 49, undated leaflet of the Alianza de la Juventud Nacionalista.

- (1940a): Legajo 13, cuerpo 3, "Nacionalismo 2", leafleat of Unión Nacionalista, titled "Enrique P. Osés”, Oct.

- (1940b): Legajo 22, cuerpo 1, "Policía de la Capital Federal", "Informe confidencial" (added by hand), [Buenos Aires], 2 Oct.

- (1941a): Legajo 19, cuerpo 7, "Provincia de Mendoza", Osés to Luis A. Vespa, Buenos Aires, 8 Feb.

- (1941b): Legajo 12, cuerpo 2, "Provincia de Santa Fe", announcement of Unión Nacionalista Santafesina (Z.N.), Rafaela, 16 June.

- (1942a): Legajo 13, cuerpo 5, "Nacionalismo 4", "Informe presentado por José María Lambruschini (en conjunto con Julio Molina con respecto a la ciudad de Córdoba), como resultado de una gira de carácter nacionalista, realizada en el mes de Mayo de 1942 por las ciudades de Córdoba, Río Cuarto, Villa Mercedes (San Luis), San Luis, San Rafael (Mendoza), Mendoza y San Juan".

- (1942b): Legajo 19, cuerpo 7, "Provincia de Mendoza”, José María Vallée, Jefe de Investigaciones, to Jefe de Policía, Mendoza, 22 [27] Aug.

Barbero, María Inés/Devoto, Fernando (1983): Los nacionalistas. Buenos Aires: Centro Editor de América Latina.

Ben-Dror, Graciela (1996): "Posturas del catolicismo argentino durante los primeros años de la Segunda Guerra Mundial”. In: Estudios Interdisciplinarios de América Latina y el Caribe, 7, 2, pp. 101-132.

- (2003): Católicos, Nazis y Judios. La iglesia argentina en los tiempos del Tercer Reich. Buenos Aires: Lumiere.

Buchrucker, Cristián (1982): "Nationalismus, Faschismus und Peronismus, 19271955”. Unpubl. PhD Diss., Freie Universität Berlin.

Cámara de Diputados (1941): Diario de Sesiones 1941, 17 Sept.

Cantón, Darío (ed.) (1968): Materiales para el estudio de la sociología política en la Argentina. Buenos Aires: Editorial del Instituto, 1.

Cerdeira, Omar et al. (1989): La Legión Cívica Argentina (1931-1932). Buenos Aires: Centro Editor de América Latina.

Crisol (Buenos Aires).

Criterio (Buenos Aires).

Devoto, Fernando J. (2002): Nacionalismo, fascismo y tradicionalismo en la Argentina moderna. Buenos Aires: Siglo XXI.

Dolkart, Ronald H. (1993): "The Right in the Década Infame, 1930-1943”. In: Mc Gee Deutsch, Sandra /Dolkart, Ronald H. (eds) (1993): The Argentine Right: Its History and Intellectual Origins, 1910 to the Present. Wilmington: SR Books, pp. 65-98.

Eatwell, Roger (1996): Fascism: A History. London: Vintage. 
Ebel, Arnold (1971): Das Dritte Reich und Argentinien. Die diplomatischen Beziehungen unter besonderer Berücksichtigung der Handelspolitik (1933-1939). Cologne: Böhlau.

El Federal (Buenos Aires).

El Pampero (Buenos Aires).

Falcoff, Mark (1982): “Argentina”. In: Falcoff, Mark/Pike, Frederick B. (eds): The Spanish Civil War, 1936-1939: American Hemispheric Perspectives. Lincoln/London: University of Nebraska Press, pp. 291-348.

Finchelstein, Federico (2002): Fascismo, liturgia e imaginario. El mito del general Uriburu y la Argentina nacionalista. Buenos Aires: FCE.

Frank, Waldo David (1944): South American Journey. London: Victor Gollancz.

Griffin, Roger (2001): “Caught in Its Own Net: Post-war Fascism Outside Europe”. In: Stein Ugelvik Larsen (ed.): Fascism Outside Europe: The European Impulse Against Domestic Conditions in the Diffusion of Global Fascism. Boulder: Social Science Monographs, pp. 46-68.

Heide, Walther (ed.) (1940): Handbuch der Zeitungswissenschaften. Leipzig: Hiersemann, 1.

Irazusta, Rodolfo and Julio (1934): La Argentina y el imperialismo británico. Buenos Aires: Ed. Argentinas Condor.

Irazusta, Rodolfo (1993): Escritos políticos completos. Buenos Aires: Independencia, 3.

Klein, Marcus (2001): “Argentine Nacionalismo before Perón: The Case of the Alianza de la Juventud Nacionalista, 1937-c. 1943”. In: Bulletin of Latin American Research, 20, 1, pp. 102-121.

- (2002): "The Legión Cívica Argentina and the Radicalisation of Argentine Nacionalismo during the Década Infame". In: Estudios Interdisciplinarios de América Latina y el Caribe, 13, 2, pp. 5-30.

Lafleur, Héctor René/Provenzano, Sergio D./Alonso, Fernando P. (1968): Las revistas literarias argentinas 1893-1967. Buenos Aires: Centro Editor de América Latina.

Loewenstein, Karl (1943): "Legislation Against Subversive Activities in Argentina". In: Harvard Law Review, 56, 8, pp. 1261-1306.

Lvovich, Daniel (2001): "La derecha argentina y las prácticas antisemitas, 1930-1943”. In: David Rock et al.: La derecha argentina. Nacionalistas, neoliberales, militares y clericales. Buenos Aires: Vergara, pp. 201-245.

- (2003): Nacionalismo y antisemitismo en la Argentina. Buenos Aires: Javier Vergara Editor.

McGee Deutsch, Sandra (1986): “The Argentine Right and the Jews, 1900-1932”. In: Journal of Latin American Studies, 18, 1, pp. 113-134.

- (1999): Las Derechas: The Extreme Right in Argentina, Brazil, and Chile 18901939. Stanford: Stanford University Press.

Metz, Allan (1993): "Gustavo Juan Franceschi and the Jews: The Overcoming of Prejudice by an Argentina Prelate”. In: Church History, 62, 2, pp. 207-220.

Montserrat, Marcelo (1998): "El orden y la libertad. Una historia intelectual de Criterio 1928-1968", Documento de Trabajo, 11. Buenos Aires: Universidad de San Andrés. 
Müller, Jürgen (1997): Nationalsozialismus in Lateinamerika. Die Auslandsorganisation der NSDAP in Argentinien, Brasilien, Chile und Mexiko, 1931-1945. Stuttgart: Hans-Dieter Heinz.

Nascimbene, Mario C./Neuman, Mauricio Isaac (1994): "El nacionalismo católico, el fascismo y la inmigración en la Argentina (1927-1943): una aproximación teórica". In: Estudios Interdisciplinarios de América Latina y el Caribe, 4, 1, pp. 115-140. Navarro Gerassi, Marysa (1968): Los nacionalistas. Buenos Aires: Ed. J. Alvarez.

Newton, Ronald C. (1992): The "Nazi Menace" in Argentina, 1931-1947. Stanford: Stanford University Press.

Osés, Enrique P. (1936): ;Y ésta es la verdad! Buenos Aires: Crisol.

- (1937): El nacionalismo ante la elección presidencial. Buenos Aires: Crisol.

- (1941a): Uniremos a los argentinos y destruiremos al liberalismo. Buenos Aires: Crisol.

- (1941b): Medios y fines del nacionalismo. Buenos Aires: n/pbl.

Politisches Archiv des Auswärtigen Amtes (PA AA) (Bonn/Berlin) (1933): R 78766, Legation to Auswärtiges Amt, Buenos Aires, 12 Dec.

- (1935): R 78766, Legation to Auswärtiges Amt, Buenos Aires, 22 Aug.

- (1936): R 104932, Embassy to Auswärtiges Amt, Buenos Aires, 3 June.

- (1938): R 104923, Report of Deputy Press Attaché, attached to Embassy to Auswärtiges Amt, Buenos Aires, 13 April.

- (1940): R 104926, Embassy to Auswärtiges Amt, Buenos Aires, 8 June.

- (1942a): R 29543, Embassy to Auswärtiges Amt, Buenos Aires, 12 May.

- (1942b): R 29544, Embassy to Auswärtiges Amt, Buenos Aires, 30 Sept.

- (1942c): R 29545, Embassy to Auswärtiges Amt, Buenos Aires, 6 Oct.

- (1942d): R 29543, Embassy to Auswärtiges Amt, Buenos Aires, 5 Nov.

- (1942e): R 29545, German Embassy to Auswärtiges Amt, Buenos Aires, 13 Nov. Payne, Stanley G. (1995): A History of Fascism: 1914-45. London: UCL Press.

Piñeiro, Elena (1997): La tradición nacionalista ante el peronismo. Itinerario de una esperanza a una desilusión. Buenos Aires: A-Z.

Potash, Robert A. (1969): The Army and Politics in Argentina, 1928-1945. Stanford: Stanford University Press.

Public Record Office, Foreign Office (PRO/FO) (London) (1940a): 420/292, Sir E. Ovey to Viscount Halifax, Buenos Aires, 12 Jan.

- (1940b): 371/24165, Sir E. Ovey to Viscount Halifax, Buenos Aires, 1 March.

- (1941a): 371/25704, Sir E. Ovey to Alfred Duff Cooper (Ministry of Information), Buenos Aires, 15 April.

- (1941b): 371/30318, Memorandum of R. H. Haven-Dyke, Air Attaché, attached to Sir E. Ovey to Mr. Anthony Eden, Buenos Aires, 11 Dec.

- (1943): 371/33511, Sir D. Kelly to Mr. Anthony Eden, Buenos Aires, 26 Feb.

- (1944): 461/3, Information Department, Bulletin no. 123, "Summary of Public Opinion Reports for the period ending the 11th February, 1944".

Quattrocchi-Woisson, Diana (1995): Los males de la memoria. Buenos Aires: Emecé. Quijada, Mónica (1991): Aires de república, aires de cruzada. La guerra civil española en Argentina. Barcelona: Sendai. 
Rapalo, María Ester (1990): "La Iglesia Católica argentina y el autoritarismo político: la revista Criterio, 1928-1931”. In: Anuario del IEHS, 5, pp. 51-69.

Rennie, Ysabel F. (1945): The Argentine Republic. New York: Macmillan.

Riesman, David (1942): "Democracy and Defamation: Fair Game and Fair Comment I". In: Columbia Law Review, 42, 7, pp. 1085-1123.

Rock, David (1987): Argentina, 1516-1987: From Spanish Colonization to Alfonsín. Berkeley: University of California Press.

- (1993): “Argentina, 1930-1946”. In: Bethell, Leslie (ed.): Argentina Since Independence. Cambridge: Cambridge University Press, pp. 173-242.

- (1995): Authoritarian Argentina: The Nationalist Movement, Its History and Its Impact. Berkeley: University of California Press.

Rouquié, Alain (1981): Poder militar y sociedad politica en la Argentina. I: hasta 1943. Buenos Aires: Emecé.

- (1982): Poder militar y sociedad política en la Argentina. II: 1943-1973. Buenos Aires: Emecé.

Ruschi Crespo, María Isabel de (1998): “Criterio”, un periodismo diferente, génesis y función. Buenos Aires: Nuevohacer/Fundación Banco de Boston.

Samyn Ducó, Emilio Juan (1978): Universalidad del nacionalismo. Buenos Aires: $\mathrm{n} / \mathrm{pbl}$.

Santillán, Diego A. de (ed.) (1960): Gran Enciclopedia Argentina. Buenos Aires: Ediar, VI: O-Q.

Senkman, Leonardo (1991): Argentina, la Segunda Guerra Mundial y los refugiados indeseables, 1933-1945. Buenos Aires: Grupo Ed. Latinoamericano.

- (1995): "El nacionalismo y el campo liberal argentinos ante el neutralismo: 19391943”. In: Estudios Interdisciplinarios de América Latina y el Caribe, 6, 1, pp. 23-49.

Spektorowski, Alberto (1993): "La imagen del judío en las corrientes integralistas y populistas del nacionalismo argentino: M. Gálvez, R. Doll, y L. Dellepiane”. In: Judaica Latinoamericana, II.

- (2003): The Origins of Argentina's Revolution of the Right. Notre Dame: University of Notre Dame Press.

Silveyra, Carlos (1933): Historia y desarrollo del comunismo en nuestro país. Buenos Aires: n/pbl.

- (1936): El comunismo en la Argentina. Buenos Aires: López.

Trifone, Victor/Svarzman, Gustavo (1993): La repercusión de la guerra civil española en la Argentina (1936-1939). Buenos Aires: Centro Editor de América Latina.

United States of America (1946): Blue Book on Argentina: Consultation Among the American Republics with Respect to the Argentine Situation. New York: Greenberg.

Volberg, Heinrich (1981): Auslandsdeutschtum und Drittes Reich. Der Fall Argentinien. Cologne/Vienna: Böhlau.

Wiener Library (1933): Press Cuttings 4, 33i, reel 9, "Die faschistische Bewegung in Argentinien“, Deutsche Allgemeine Zeitung, 9 Oct. 
Zanatta, Loris (1996): Del estado liberal, a la nación católica. Iglesia y ejército en los orígenes del peronismo, 1930-1943. Buenos Aires: Universidad Nacional de Quilmes.

Zuleta Álvarez, Enrique (1975): El nacionalismo argentino. Buenos Aires: La Bastilla. 